Rozprawa Pani dr Jolanty Dybały jest na gruncie polskim bez wątpienia najgruntowniejszą analizą stosunku Ojców Kapadockich i Jana Chryzostoma do roli i miejsca kobiety w społeczności chrześcijańskiej. Została napisana z ogromną delikatnością. Autorka starała się zachować obiektywizm nawet w stosunku do najbardziej „karkołomnych” twierdzeń rzeczonych autorów. Lektura książki inspiruje do stawiania dalszych pytań. Odsłania też pewne rozdarcie autorów chrześcijańskich piszących w IV wieku pomiędzy obowiązującym prawodawstwem państwowym a Nowym Testamentem, w którym na plan pierwszy wysuwa się w tym kontekście Corpus Paulinum. Recenzowana praca ma szansę stać się na gruncie polskim ważnym punktem odniesienia $\mathrm{w}$ dyskusjach na temat chrześcijańskiego rozumienia miejsca kobiety w okresie złotego wieku patrystyki.

Piotr Kochanek - Lublin, KUL

\title{
Paweł FILIPCZAK, Bunty $i$ niepokoje $w$ miastach wczesnego Bizancjum (IV wiek n.e.), Byzantina Lodziensia 12, Lódź 2009, Wydawnictwo Uniwersytetu Lódzkiego, ss. 236.
}

Książka niniejsza składa się z czterech rozdziałów. Pierwszy z nich (ss. 21-49) analizuje problem „Władze miejskie i państwowe na straży porządku publicznego". Owych 29 stron posiada 114 przypisów, co daje średnio 3,931 przypisu na stronę. Rozdział drugi, obejmujący 55 stron (ss. 51-105), ma za przedmiot dociekań: „Bunty, rozruchy i niepokoje wywołane kłopotami aprowizacyjnymi oraz opodatkowaniem - przykład Antiochii nad Orontesem”. Jego dokumentacja to 240 przypisów, czyli 4,363 przypisu na stronę. Najdłuższa, trzecia część rozprawy, zatytułowana „Rozruchy wywołane kontrowersją ariańską, rywalizacją chrześcijaństwa z pogaństwem oraz pogarszającą się pozycją Żydów”, rozpatruje to zagadnienie na 62 stronach (ss. 107-168) i posiada 263 przypisy $(4,241$ przypisu na stronę). Wreszcie ostatni, czwarty rozdział, noszący tytuł „Bunt w Tesalonice (390 r.). Przykład konfliktu wywołanego emocjami sportowymi”, to 38 stron tekstu (ss. 169-206), na których widnieją 183 przypisy (4,815 przypisu na stronę). Ten zasadniczy korpus rozprawy poprzedza wstęp (ss. 9-19), którego 11 stron zawiera 39 przypisów (3,272 przypisu na stronę), a konkluduje zakończenie (ss. 207-217). Podstawowy zatem tekst pracy to 206 stron wywodów, opatrzonych 836 przypisami, co daje średnią 4,058 przypisu na stronę. Należy zaznaczyć, że przypisy są zwykle dość obszerne i wyjaśniają wiele ważnych kwestii pobocznych, dla których nie ma miejsce w głównym toku wywodów. Dzięki temu te ostatnie zyskują na jasności i rzeczowości. Z kolei rozbudowane, chciałoby się wręcz powiedzieć barokowe tytuły rozdziałów mają jednak tę zaletę, że oddaja jednoznacznie treść poszczególnych części rozprawy. Drugim pozytywnym zabiegiem Autora jest umieszczenie na końcu każdego rozdziału paragrafu podsumowującego, opatrzonego tytułem „Wnioski”. W ten sposób czytelnik otrzymuje klarowny zbiór wyników szczegółowych analiz Autora. Ich syntetyczne ujęcie 
podano raz jeszcze w zakończeniu. Ta „cykliczna” struktura podsumowań sprawia, że czytelnik łatwiej przyswaja sobie wyniki badań.

Elementami domykającymi pracę są: Bibliografia (ss. 219-230) oraz napisane w języku angielskim Streszczenie (ss. 231-234). Bibliografia została podzielona na źródła i opracowania. Autor cytuje tu 69 źródeł (w tym 14 przekładów polskich) i 232 opracowania, z których 98, czyli nieco ponad 42\%, to książki i artykuły w języku polskim. Pozostałe pozycje to głównie prace napisane po angielsku. Jednak Autor nie ograniczył się wyłącznie to tego języka, ponieważ zawarł w swej bibliografii także 35 opracowań w języku francuskim, 13 w niemieckim, 3 napisane po rosyjsku oraz $1 \mathrm{w}$ języku greckim. Świadczy to dobrze zarówno o znajomości języków, jak i o horyzontach intelektualnych Autora.

Rozdz. I ma charakter swoistego katalogu urzędników odpowiedzialnych za bezpieczeństwo publiczne. Jest to bardzo użyteczne zestawienie terminów technicznych, jakimi określano poszczególnych funkcjonariuszy wraz z omówieniem zakresu ich kompetencji. W przypisach Autor odsyła do bogatej literatury przedmiotu. Dzięki temu rozdziałowi odciążono pozostałe części rozprawy od żmudnych i zakłócających tok narracji ekskursów wyjaśniających znaczenie i funkcje poszczególnych urzędników, wymienianych w analizowanych tam źródłach. Zabieg ten wpłynął bardzo pozytywnie na strukturę następnych rozdziałów omawianego tu opracowania.

Zasadnicza część książki to rozdziały II-IV. Poświęcony Antiochii rozdz. II ilustruje przyczyny, przebieg i skutki tumultów w metropolii nad Orontesem, które wybuchły pomiędzy 313 a 387 rokiem. Jasny wykład pozwala czytelnikowi sprawnie ogarnąć zarówno sam problem, jak i kwestię jego bazy źródłowej oraz zorientować się we współczesnej literaturze przedmiotu. Autor porusza się sprawnie w analizowanej materii. Rozdz. III, poświęcony niepokojom na tle wyznaniowym, wydaje się być dla dr. P. Filipczaka sporym wezwaniem. Już sama próba ujęcia tych kwestii na 62 stronach jest zadaniem trudnym. Mogło to być podyktowane chociażby chęcią utrzymania proporcji rozdziałów. Autor słusznie odwołał się tutaj przede wszystkim do źródeł, które analizuje w sposób inteligentny i rzeczowy. Natomiast w przypadku literatury pomocniczej dr P. Filipczak oparł się głównie na opracowaniach polskich lub na polskojęzycznych przekładach. Autor uzyskałby prawdopodobnie znacznie lepszy ogląd poruszanych w tym rozdziale zagadnień, gdyby odwołał się do literatury obcojęzycznej. Ostatni, czwarty rozdział dotyczący wydarzeń w Tesalonice w roku 390, tworzy zamkniętą i dobrze osadzoną w źródłach całość. Ich analiza, podobnie jak w poprzednich rozdziałach, zasługuje na uznanie.

Autor stara się bardzo skrupulatnie analizować źródła, wydobywając z nich w sposób wieloaspektowy potencjalne możliwości ich interpretacji. W tym celu posługuje się także sugestiami zawartymi w licznych opracowaniach. Czytając te cenne, choć niekiedy dyskusyjne wywody, odnosi się wrażenie, że w bogatym arsenale literatury pomocniczej zabrakło Autorowi dwóch pozycji, które jego styl rozumowania i analizę źródeł mogły bardzo pogłębić. Chodzi o znaną monografię 
belgijskiego filologa klasycznego Josepha Bideza (1867-1945), wydaną po raz pierwszy w roku 1930: La vie de l'empereur Julien (reprint: 1965 i 2012) oraz o cenioną syntezę Manlio Simonettiego (ur. 1926) z roku 1975: La crisi ariana nel $I V$ secolo. Lektura tych autorów byłaby bardzo pomocna przy interpretacji wielu kwestii szczegółowych, poruszanych w recenzowanym opracowaniu. Pozwoliłaby ona Autorowi na głębsze wniknięcie w analizowane źródła. W konsekwencji Jego słuszne dążenie do wszechstronności analiz i obiektywizmu wysnuwanych wniosków zyskałoby realne wsparcie w przemyśleniach i w logice argumentacji wytrawnych znawców poruszanych przezeń kwestii. Niemniej jednak Autorowi należą się słowa uznania za uczciwie i rzetelnie wykonaną pracę heurystyczną i hermeneutyczną.

Na ten przykładny warsztat rzuca niewielki cień pewna ilość „błędów i wypaczeń": s. 11, przyp. 13: jest: „Actes colloque”, powinno być: „Actes du colloque”; s. 12 (lin. 10 od góry), jest: „poźnoantycznej”, powinno być: „późnoantycznej”; s. 12, przyp. 16, jest: „Archeological”, powinno być: „Archaeological”; s. 15 (lin. 21 od góry), jest: „Thesaurus Lingue Graece”, powinno być: „Thesaurus Linguae Graecae”; s. 26 (lin. 17 i 21 od góry), jest: „eirenerchy”, powinno być: „eirenarchy”; s. 30 (lin. 7 od góry): jest „eirenerachowie”, powinno być: ,eirenarchowie”; s. 44 (lin. 2 od dołu), jest: ,nas terenie”, powinno być: „na terenie”; s. 48 (lin. 15 od góry): jest: „funkcjnariusza”, powinno być: „funkcjonariusza”; s. 76 (lin. 14 od góry), jest: „,rozłoszczony”, powinno być: „rozzłoszczony”; s. 96, przyp. 223, jest: „magister miltum”, powinno być: „magister militum”; s. 141 (lin. 9 od dołu), jest: „strać”, powinno być: „starć”; s. 151 (lin. 12 od góry): jest: „wystapienie pogan nie był wyrazem”, powinno być: „wystapienie pogan nie było wyrazem”; s. 159 (lin. 8 od góry), jest: „fragmnet”, powinno być: „fragment”; s. 164 (lin. 1 od góry), jest: „datują na najczęściej na rok”, powinno być: „datują najczęściej na rok”; s. 184 (lin. 6 od dołu), jest: „W myśli”, powinno być: „W myśl”; s. 187 (lin. 3 od dołu), jest: „zaczęła się domagać się”, powinno być: ,zaczęła się domagać”;

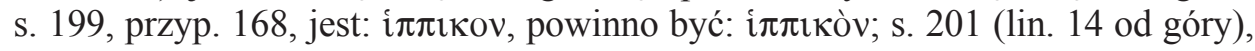
jest: ,jaki i z czasów”, powinno być: ,jak i z czasów”; s. 219 (lin. 11 od góry), jest: „Wolgang”, powinno być: „Wolfgang”; s. 220 (lin. 21 od góry), jest: „ex rec. I. Bekkerus”, powinno być: „,ex rec. I. Bekkeri”; s. 221 (lin. 6 od dołu), jest: „Miltary”, powinno być: „Military”; s. 222 (lin. 20 od góry), jest: „Actes colloque”, powinno być: „Actes du colloque”; s. 222 (lin. 25 od góry), jest: „Le gouverneurs romain”, powinno być: „Le gouverneur romain”; s. 222 (lin. 25 od góry), jest: „Les directions possibles de l'enquête”, powinno być: „Orientations de l'enquête”; s. 222 (lin. 26 od góry), jest: „Antiquite tardive”, powinno być: „Antiquité Tardive”; s. 222 (lin. 12 od dołu), jest: „Mélange d'histoire”, powinno być: „Mélanges d'histoire"; s. 222 (lin. 11 od dołu), jest: „,soixante-dixiéme”, powinno być: „soixante-dixième”; s. 224 (lin. 15 od góry), jest: „Urban Vilolence”, powinno być: „Urban Violence”; s. 224 (lin. 16 od góry), jest: „Archeological”, powinno być: „Archaeological”; s. 226 (lin. 21 i 40 od góry), jest: „Ausfstieg” (2x), powinno być: „Aufstieg” (2x); s. 226 (lin. 22 i 41 od góry), jest: „romischen” (2x), powinno 
być: „römischen” (2x); s. 226 (lin. 25 od góry), jest: „Gedeute”, powinno być: „Gedeutete”; s. 226 (lin. 26 od góry), jest: „3.-6. Jh. N. Ch.”, powinno być: ,3.-6. Jh. n. Chr.”; s. 226 (lin. 26 od góry), jest: „Sttutgart”, powinno być: „Stuttgart”; s. 228 (lin. 14 od góry), jest: „Actes colloque”, powinno być: „Actes du colloque”; s. 228 (lin. 25 od góry), jest: „l'empire romaine”, powinno być: „l'Empire romain”; s. 229 (lin. 11 od dołu), jest: „rozdawnictwa”, powinno być: ,rozdawnictwo”.

Ponadto w bibliografii (źródła) na s. 221 pojawiają się po Historia ecclesiastica Rufina trzy pisma Ambrożego oraz traktat Augustyna De civitate Dei. Ten „chochlik komputerowy” zakłóca nieco tok analizy pozycji zawartych w bardzo skądinąd instruktywnej i dobrze dobranej bibliografii. Ponadto cytując w tejże bibliografii (s. 220) dzieło Jordanesa O pochodzeniu i czynach Gotów w przekładzie E. Zwolskiego z roku 1984, Autor podał słusznie, że znajduje się ono w rozprawie E. Zwolskiego: Kasjodor i Jordanes. Historia gocka czyli scytyjska Europa (Lublin 1984). Zapomniał jednak dopisać stron, na których ów przekład się znajduje; chodzi zaś o strony: 91-146. Natomiast na s. 223 rzeczonej bibliografii dwóch autorów opracowań, a mianowicie M. Dzielska i W. Dziewulski, ,wypadło” z porządku alfabetycznego. Ponadto w omawianej bibliografii źródeł Autor zapomina niekiedy, cytując PG i PL, że niektóre wydania posiadają kolumny, które są dzielone literami od A do D; ta sama nieścisłość powtarza się w przypisach.

Przedstawiony wyżej wybiórczy zestaw zauważonych mankamentów technicznych nie podważa jednak w niczym eminentnego wkładu Autora do polskiej bibliografii bizantynologicznej. Kwestie społeczne antyku ujmowane w świetle najnowszych badań dotykają przecież tego, co w historiografii najistotniejsze - człowieka w czasie i przestrzeni. Stąd podjęty przez dra P. Filipczaka temat świadczy nie tylko o jego badawczych zainteresowaniach, lecz również o Jego empatycznej wrażliwości i otwarciu na człowieka jako takiego.

Recenzowana praca jest kolejnym opracowaniem reprezentanta „Łódzkiej Szkoły Bizantynistycznej”, ucznia prof. Waldemara Cerana (1936-2009). Jest ona w jakimś sensie kontynuacją młodzieńczych zainteresowań Mistrza społeczeństwem późnoantycznych metropolii, których owocem była opublikowana w 1969 roku rozprawa pt. Rzemieślnicy $i$ kupcy $w$ Antiochii $i$ ich ranga społeczna (II połowa IV wieku). Na tej linii plasuje się również ważna w historiografii polskiej praca zbiorowa łódzkich badaczy z roku 2011: Konstantynopol - Nowy Rzym. Miasto i ludzie w okresie wczesnobizantyńskim, gdzie dr P. Filipczak jest autorem rozdziału piątego, a współautorem pierwszego. Temat pokrewny powyższemu aspektowi badań szkoły łódzkiej podjął w Lublinie ks. prof. Piotr Szczur, wydając w roku 2008 pracę habilitacyjną pt. Problematyka społeczna w późnoantycznej Antiochii na podstawie nauczania homiletycznego Jana Chryzostoma. Istnieje zatem w Polsce pewna ciagłość pokoleniowa badań nad późnoantyczną społecznością miejską. Dr Paweł Filipczak wyrasta dziś na czołowego jej reprezentanta i znawcę przedmiotu. 